\title{
Seroprevalence of anti-Neospora caninum antibodies in cows of North-Eastern Algeria
}

\author{
Kamel Miroud ${ }^{1}$, Amar Benlakehal ${ }^{2}$ and Rachid Kaidi ${ }^{3}$
}

1. Research Laboratory of Epidemio-Surveillance, Production and Reproduction, Health, Cellular Experimentation and Therapy of Domestic and Wild Animals, Department of Veterinary Sciences, University Chadli Bendjedid, BP 73,

El-Tarf 36000, Algeria; 2. Department of Applied Biology, Institute of Biology, University Larbi Tebessi, Route de Constantine, Tebessa 12000, Algeria; 3. Veterinary Institute, University Saad Dahleb, Route de Soumaa, BP 270, Blida 9000, Algeria.

Corresponding author: Kamel Miroud, e-mail: k_miroud@yahoo.fr

Co-authors: AB: lakhalammar@yahoo.fr, RK: kaidirachid@yahoo.fr

Received: 22-01-2019, Accepted: 16-04-2019, Published online: 08-06-2019

doi: 10.14202/vetworld.2019.765-768 How to cite this article: Miroud K, Benlakehal A, Kaidi R (2019) Seroprevalence of anti-Neospora caninum antibodies in cows of North-Eastern Algeria, Veterinary World, 12(6): 765-768.

\begin{abstract}
Aim: The present cross-sectional study aimed at assessing the seroprevalence of Neospora caninum infection both at herd and within herd and at determining risk factors that are associated with its seropositivity.

Materials and Methods: A total of 90 cows distributed over seven herds located in two North-Eastern Algerian provinces were blood sampled in order to be tested for the presence of antibodies against $N$. caninum using a commercially available enzyme-linked immunosorbent assay kit.

Results: The individual seroprevalence of $N$. caninum was found to be $12.22 \%$, and six of the seven herds tested had at least one seropositive cow. The logistic regression model revealed that abortion (odds ratio $[\mathrm{OR}]=29.15)$ and parity $(\mathrm{OR}=7.38)$ were positively associated with the seropositivity of animals on an individual basis.

Conclusion: The study confirms the existence of $N$. caninum infection in cattle in North-Eastern Algeria. However, a widespread infection rate of $85.71 \%$ and its significant statistical association with previous abortion $(O R=29.15)$ need further investigations.
\end{abstract}

Keywords: cows, enzyme-linked immunosorbent assay, Neospora caninum, North-Eastern Algeria, reproduction.

\section{Introduction}

Neospora caninum is an obligatory, intracellular, apicomplexan protozoan parasite [1], which is distributed worldwide [2]. It was first recognized in dogs in Norway in 1984 [3] and was identified as a new protozoan for the first time in 1988 [4]. This parasite, considered as the major cause of abortion in cattle, can affect other species also $[5,6]$. Other reproductive problems such as stillbirth, early embryonic mortality, and embryonic resorption have been related to $N$. caninum. The economic losses are due to a decrease in milk yield in those cows that abort, their culling, and a reduced rate of growth and feed efficiency [7-9]. Dogs [10], coyotes [11], and Australian dingoes [12] are recognized as the definitive hosts for $N$. caninum, whereas cattle and many other species (deer, goats, sheep, horses, and water buffalo) are intermediate hosts $[2,6]$. The life cycle of $N$. caninum consists of vertical transmission and/or a horizontal transmission [2,13]. Many serological tests, among which an enzyme-linked immunosorbent assay

Copyright: Miroud, et al. Open Access. This article is distributed under the terms of the Creative Commons Attribution 4.0 International License (http://creativecommons.org/licenses/by/4.0/), which permits unrestricted use, distribution, and reproduction in any medium, provided you give appropriate credit to the original author(s) and the source, provide a link to the Creative Commons license, and indicate if changes were made. The Creative Commons Public Domain Dedication waiver (http://creativecommons.org/ publicdomain/zero/1.0/) applies to the data made available in this article, unless otherwise stated.
(ELISA) is widely used, detect antibody against $N$. caninum and are commercially available $[14,15]$. These tests are used in epidemiological surveys to assess $N$. caninum infection prevalence, to examine the relationship between exposure to $N$. caninum and outcomes (abortion, reduced milk yield, and cattle culling), and to determine the individual- and herdlevel risk factors for $N$. caninum seropositivity $[9,15]$. $N$. caninum antibody detection in aborted cows' serum is only indicative of contact with these protozoa and does not prove that neosporosis is the cause of abortion $[9,15]$.

In Algeria, research studies carried out in order to detect or isolate $N$. caninum are scarce. These are limited to the detection of $N$. caninum in the spleen and liver of naturally infected dogs through the use of polymerase chain reaction (PCR) [16], a serological survey of abortive agents in two cattle farms located in the central part of Algeria [17], a study of the risk factors associated with $N$. caninum infection in the north and northeast of Algeria [18], and a seroprevalence study of $N$. caninum in dairy cattle farms in central-northern Algeria [19] and in eastern Algeria [20].

The objectives of the study were two-fold: To estimate the seroprevalence of $N$. caninum antibodies in cattle and to correlate the results with the following risk factors: History of the most recent abortion recorded, parity, breed, and location, measured on an individual basis in two Algerian provinces. 


\section{Materials and Methods}

\section{Ethical approval}

Ethical approval is not required for such type of study. Blood samples were collected as per standard collection technique without any stress or harm to the animals.

\section{Study population and sampling}

A total of 90 adult cows making up seven randomly selected herds located in two Algerian eastern provinces, namely Tebessa and Guelma, were blood sampled. Data related to the reproductive history of the animals (abortion and absence of abortion), breed (native and exotic), and parity (multiparous and primiparous) were collected from breeders and their veterinarians.

\section{Blood collection}

$10 \mathrm{ml}$ of blood was collected from the jugular vein of each cow, using vacutainer tubes without anticoagulant. The sera were stored at $-20^{\circ} \mathrm{C}$ at the Regional Veterinary Laboratory (El Khroub, Province of Constantine) until analysis.

\section{Laboratory analysis}

Serum samples $(n=90)$ were tested for anti- $N$. caninum antibodies through a commercial ELISA test "CHEKIT Neospora ${ }^{\circledR}$ (IDEXX Laboratory, Netherlands)." They were tested in duplicates according to the manufacturer's instructions. The results were read using a photometer at a wavelength of $450 \mathrm{~nm}$. The $\mathrm{S}_{450} \mathrm{~nm}$ of duplicates was averaged, and the values of both the positive control and the samples were corrected by subtracting the $\mathrm{S}_{450} \mathrm{~nm}$ of the negative control as presented below:

Sample: $\mathrm{OD}_{\text {sample }}-\mathrm{OD}_{\text {negative }}$

Positive control: $O D_{\text {positive }}-\mathrm{OD}_{\text {negative }}$

The results were expressed as percentages using the following formula:

$$
\operatorname{Value}(\%)=\frac{\mathrm{OD}_{\text {sample }}-\mathrm{OD}_{\text {negative }}}{\mathrm{OD}_{\text {positive }}-\mathrm{OD}_{\text {negative }}} \times 100 \%
$$

\section{Statistical analysis}

A cow is considered to be seropositive for $N$. caninum if the $\mathrm{S} / \mathrm{P}$ ratio is $\geq 30 \%$ (manufacturer's instructions). The seroprevalence rate is the number of cows that are seropositive over the total number of sampled cows, and a herd is defined as seropositive when at least one of its cows test positive to $N$. caninum. Risk factor analysis was performed in two steps: First, the independent variables were subjected to univariate analysis using the Chi-squaretest $(n>5)$ or Fisher's exact test $(\mathrm{n}<5)[21]$ and second, the logistic regression [21] was used to build up a multivariate model to explain the dependent variable (serological status) in relation to the independent variables which had $\mathrm{p}<0.10$ after being subjected to the univariate analysis. The relationship between the serological status and putative risk factors was determined using odds ratio (OR). The statistical significance was determined at $\mathrm{p} \leq 0.05$. The statistical software package IBM SPSSUSA (version 15.0 for Windows 7, 2006) was used.

\section{Results}

The analysis of the data collected showed that $12.22 \%$ of cows and $85.71 \%$ of herds were seropositive; the seroprevalences were at the individual level (17.78\% and 6.67\%) and at a herd level (100\% and $33.33 \%$ ) in Tebessa and Guelma, respectively (Table-1).

\section{Risk factor analysis}

The history of abortion, parity, and breed of cattle were the only three independent variables out of the four investigated that were statistically significantly associated $(\mathrm{p}<0.10)$ with seropositivity as shown by the univariate analysis; when these three variables were subjected to multivariate analysis (Table-2), the history of abortion $(\mathrm{p}=0.000, \mathrm{OR}=29.150)$ and parity $(p=0.046$, OR: 7.380$)$ proved to be the sole variables significantly associated with seropositivity (Table-3).

\section{Discussion}

The results of data analysis have to be interpreted with care because of the relatively small number of animals that were sampled (90 cows); the latter was mainly due to the refusal of many breeders to take part in the study. The result obtained proved, for the first time, the presence of $N$. caninum in cattle in Tebessa and Guelma. The individual seroprevalence $(12.22 \%)$ recorded was lower than that reported by previous studies: $19.64 \%$ in North-Eastern Algeria [18], 32.8\% in central-north Algeria [17], and $16 \%$ in Constantine [20] but similar to that reported $(12.37 \%)$ in a study carried out in five provinces of central-northern Algeria [19]. The discrepancy in the percentage recorded could be due to the serological type test used; cutoff level used to determine the exposure, region, sample size, sampling frame; and livestock farming [2,22], all known to exert a different effect on the results.

The herd seroprevalence rate recorded $(85.71 \%)$ (Table-1) showed that $N$. caninum infection was highly

Table-1: Seroprevalence (\%) of Neospora caninum infection at individual and herd levels.

\begin{tabular}{|c|c|c|c|c|c|c|}
\hline \multirow[t]{2}{*}{ Provinces } & \multicolumn{3}{|c|}{ Herd level } & \multicolumn{3}{|c|}{ Individual level } \\
\hline & $\begin{array}{c}\text { Number of } \\
\text { herds }\end{array}$ & $\begin{array}{c}\text { Number of } \\
\text { positives }\end{array}$ & Seroprevalence (\%) & $\begin{array}{c}\text { Number of } \\
\text { cows }\end{array}$ & $\begin{array}{c}\text { Number of } \\
\text { positives }\end{array}$ & Seroprevalence (\%) \\
\hline Tebessa & 4 & 4 & 100 & 45 & 8 & 17.78 \\
\hline Guelma & 3 & 2 & 66.67 & 45 & 3 & 6.67 \\
\hline Overall & 7 & 6 & 85.71 & 90 & 11 & 12.22 \\
\hline
\end{tabular}


Table-2: Univariate analysis of the risk factors associated with the seroprevalence of sampled cows.

\begin{tabular}{llccccc}
\hline Factors & Categories & Number tested & Number of positive & \% positive & p-value & p Fisher's exact test \\
\hline Abortion & Yes & 12 & 5 & 41.67 & 0.0007 & NA \\
& No & 78 & 6 & 7.69 & - & 0.04114 \\
\multirow{2}{*}{ Barity } & Multiparous & 47 & 9 & 19.15 & -1.65 & 0.05566 \\
& Primiparous & 43 & 2 & 25.00 & - & \\
Province & Native & 32 & 8 & 6.38 & & 0.127 \\
& Exotic & 47 & 3 & 17.78 & - & \\
& Tebessa & 45 & 8 & 6.67 & & \\
& Guelma & 45 & 3 & & & \\
\hline
\end{tabular}

disseminated across the sampled herds. Although this result is of a low statistical significance due to the limited number of herds sampled. Its clinical importance is, however, greater if one takes into account the high performance of ELISA test (high sensibility and specificity: Se and $\mathrm{Sp}>95 \%$ ) $[14,15,23]$, the capacity of its horizontal and vertical transmission [2,13], and the absence of prophylactic measures as it is the case in Algeria.

The cows with the most recent abortion history were more likely to be seropositive $(\mathrm{p}=0.000$, $\mathrm{OR}=29.15)$. This is in accordance with what was reported in some studies [18,24-26] where the estimated OR indicated a higher proportion of seropositivity in cattle with than those without an antecedent of reproductive problems. Although $N$. caninum is among the most important abortion-causative agents in cattle worldwide, a significant statistical link between abortion and seropositivity did not fully implicate $N$. caninum as an abortive agent [27]. This can be due to the fact that (a) conclusive data can be obtained only by prospective cohort and experimental studies or direct diagnostic test $[2,28,29]$ and not through cross-sectional studies because they do not take into account the temporal relationship between the risk factors and the outcome [21]; (b) incidence of other abortive agents may mask such an association or decrease the power of analytical techniques to detect it [30]; and (c) ELISA is an indirect diagnostic method in that the detection of antibodies from $N$. caninum bovine serum is only indicative of a contact with these protozoa and does not confirm neosporosis as a cause of abortion, while the negative serological result for $N$. caninum excludes its implication in abortion [31]. To confirm that $N$. caninum is responsible for abortion, other diagnostic techniques such as PCR analysis, histopathologic findings, or immunohistochemical staining are required $[7,27,28]$.

A relationship between the multiparity variable and seropositivity to $N$. caninum ( $\mathrm{p}=0.046, \mathrm{OR}=7.38$ ), as reported by previous studies [30,32], was observed in the present work. These authors suggest that the horizontal transmission through oocyst ingestion is particularly important in some herds. This relationship could also be the result of the absence of selective culling of animals seropositive to $N$. caninum as well as that of neosporosis screening in the herds under study [2].
Table-3: Result analysis, through the multiple logistic regression, of risk factors associated with the seroprevalence of sampled cows.

\begin{tabular}{lccccc}
\hline $\begin{array}{l}\text { Risk } \\
\text { factors }\end{array}$ & B & SE $_{\boldsymbol{\beta}}$ & p-value & OR & CI 95.0\% OR \\
\hline Breed & 1.099 & 0.888 & 0.216 & 3.001 & $0.527-17.102$ \\
*Parity & 1.999 & 1.004 & 0.046 & 7.380 & $1.032-52.797$ \\
*Abortion & 3.372 & 0.88 & 0.000 & 29.150 & $5.193-163.623$
\end{tabular}

$\beta=$ Standard coefficient, $S E=$ Standard error. $\mathrm{OR}=$ Odds ratio, $\mathrm{CI}=$ Confidence interval, $* \mathrm{p}<0.05$

\section{Conclusion}

The present study confirms, for the first time, the existence of $N$. caninum infection in cattle in North-Eastern Algeria. However, the widespread infection rate (85.71\%) and its statistically significant association with previous abortion $(\mathrm{OR}=29.15)$ require further investigations through more epidemiological studies in order to assess the real infection incidence and to implement surveillance programs to control any eventual progression and transmission of the disease.

\section{Authors' Contributions}

KM designed and carried out the research study along with $\mathrm{AB}$, who did most of the field work. RK helped with the design and correction of the manuscript. All authors read and approved the final manuscript.

\section{Acknowledgments}

The authors wish to thank Professor G. England, Dean of Nottingham Veterinary School, who provided us the ELISA kit, and W. Wapenaar, Clinical Associate Professor, who proofread the manuscript.

\section{Competing Interests}

The authors declare that they have no competing interests.

\section{Publisher's Note}

Veterinary World remains neutral with regard to jurisdictional claims in published institutional affiliation.

\section{References}

1. Jin, X., Li, G., Zhang, X., Gong, P., Yu, Y. and Li, J. (2017) Activation of a Neospora caninum EGFR-like kinase facilitates intracellular parasite proliferation. Front. Microbiol., 8: 1980. 
2. Dubey, J.P., Schares, G. and Ortega-Mora, L.M. (2007) Epidemiology and control of neosporosis and Neospora caninum. Clin. Microbiol. Rev., 20(2): 323-367.

3. Bjerkås, I., Mohn, S.F. and Presthus, J. (1984) Unidentified cyst-forming sporozoan causing encephalomyelitis and myositis in dogs. Z. Parasitenkd., 70(2): 271-274.

4. Dubey, J.P., Carpenter, J.L., Speer, C.A., Topper, M.J. and Uggla, A.N.D. (1988) Newly recognized fatal protozoan disease of dogs. J. Am. Vet. Med. Assoc., 192(9): 1269-1285.

5. Almería, S. and López-Gatius, F. (2013) Bovine neosporosis: Clinical and practical aspects. Res. Vet. Sci., 95(2): 303-309.

6. Donahoe, S.L., Lindsay, S.A., Krockenberger, M., Phalen, D. and Šlapeta, J. (2015) A review of neosporosis and pathologic findings of Neospora caninum infection in wildlife. Int. J. Parasitol Parasites Wildl., 4(2): 216-238.

7. Pooley, F., Remnant, J. and Wapenaar, W. (2014) Neospora in cattle and dogs: An update. Livestock, 19(3): 153-157.

8. Reichel, M.P., McAllister, M.M., Pomroy, W.E., Campero,C., Ortega-Mora, L.M. and Ellis, J.T. (2014) Control options for Neospora caninum is there anything new or are we going backward? Parasitology, 141(11): 1455-1470.

9. McAllister, M.M. (2016) Diagnosis and control of bovine neosporosis. Vet. Clin. North Am. Food Anim. Pract., 32(2): 443-463.

10. McAllister, M.M., Dubey, J.P., Lindsay, D.S., Jolley, W.R., Wills, R.A. and McGuire, A.M. (1998) Rapid communication: Dogs are definitive hosts of Neospora caninum. Int. J. Parasitol., 128(9): 1473-1479.

11. Gondim, L.F., McAllister, M.M., Pitt, W.C. and Zemlicka, D.E. (2004) Coyotes (Canis latrans) are definitive hosts of Neospora caninum. Int. J. Parasitol., 34(2): 159-161.

12. King, J.S., Šlapeta, J., Jenkins, D.J., Al-Qassab, S.E., Ellis, J.T. and Windsor, P.A. (2010) Australian dingoes are definitive hosts of Neospora caninum. Int. J. Parasitol., 40(8): 945-950.

13. Moore, D.P. and Venturini, M.C. (2018) Neospora. In: Parasitic Protozoa of Farm Animals and Pets. Springer, Switzerland. p125-148.

14. Campero, L.M., Minke, L., Moré, G., Rambeaud, M., Bacigalupe, D., Moore, D.P., Hecher, Y., Campero, C.M., Schares, G. and Venturini, M.C. (2015) Evaluation and comparison of serological methods for the detection of bovine neosporosis in Argentina. Rev. Argent. Microbiol., 47(4): 295-301.

15. Guido, S., Katzer, F., Nanjiani, I., Milne, E. and Innes, E.A. (2016) Serology-based diagnostics for the control of bovine neosporosis. Trends Parasitol., 32(2): 131-143.

16. Ghalmi, F., China, B., Kaidi, R., Daube, G. and Losson, B. (2008) Detection of Neospora caninum in dog organs using real-time PCR systems. Vet. Parasitol., 155(1-2): 161-167.

17. Dechicha, A., Gharbi, S., Kebbal, S., Chatagnon, G., Tainturier, D., Ouzrout, R. and Guetarni, D. (2010) Serological survey of etiological agents associated with abortion in two Algerian dairy cattle breeding farms. J. Vet. Anim. Health, 2(1): 1-5.

18. Ghalmi, F., China, B., Ghalmi, A., Hammitouche, D. and Losson, B. (2012) Study of the risk factors associated with Neospora caninum seroprevalence in Algerian cattle populations. Res. Vet. Sci., 93(2): 655-661.

19. Achour, K., Ben-Mahdi, M.H., Akkou, M. and Teniou,xR. (2012) Séroprévalence de Neospora caninum dans les élevages bovins laitiers de la région centre nord de l'Algérie. Rev. Sci. Tech. Int. Epiz., 31(3): 953-958.

20. Bouaziz, O., Dib, A.L., Aimeur, R., Lakhdara, N., Bouaziz, A. and Brerhi, E. (2013) Seroprevalence of Neospora caninum in dairy cattle in Eastern Algeria. Ann. Biol. Res., 4(11): 76-77.

21. Thrusfield, M. (2008) Veterinary Epidemiology. $3^{\text {rd }}$ ed. United Kindom: Blackwell Publishing Company. p266284,610 .

22. Fort, M., Edelsten, M., Maley, S. and Innes, E. (2015) Seroepidemiological study of Neospora caninum in beef and dairy cattle in La Pampa, Argentina. Acta Parasitol.,60(2): 275-282.

23. Chatziprodromidou, I.P. and Apostolou, T. (2018) Diagnostic accuracy of enzyme-linked immunosorbent assay (ELISA) and immunoblot (IB) for the detection of antibodies against Neospora caninum in milk from dairy cows. Epidemiol. Infect., 146(5): 577-583.

24. Klauck, V., Machado, G., Pazinato, R., Radavelli, W.M., Santos, D.S., Berwaguer, J. C., Braunig, P., Vogel, F.F. and Da Silva, A.S. (2016) Relation between Neospora caninum and abortion in dairy cows: Risk factors and pathogenesis of disease. Microb. Pathol., 92: 46-49.

25. Llano, H.A.B., Guimarães, M.S., Soares, R.M., Polo, G. and da Silva, A.C. (2018) Seroprevalence and risk factors for Neospora caninum infection in cattle from the Eastern Antioquia, Colombia. Vet. Anim. Sci., 6: 69-74.

26. Martinez, B.A.F., Leotti, V.B., Borba, M.R., Silva, G.D.S. and Corbellini, L.G. (2017) Can hierarchical modeling improve our understanding of bovine abortion due to Neospora caninum infection? Vet. Parasitol., 237: 77-82.

27. Schetters, T., Heuer, C., Nicholson, C., Russel, D. and Weston, J. (2004) Field study in dairy cattle from New Zealand. Intervet symposium: Bovine neosporosis. Vet Parasitol., 125(1-2): 137-146.

28. Jenkins, M., Baszler, T., Björkman, C., Schares, G. and Williams, D. (2002) Diagnosis and seroepidemiology of Neospora caninum-associated bovine abortion. Int. J. Parasitol., 32(5): 631-636.

29. Dubey, J.P., Hemphill, A., Calero-Bernal, R. and Schares, G. (2017) Neosporosis in Animals. CRC Press, Taylor \& Francis Group. London. p203-225.

30. Moore, D.P., Pérez, A., Agliano, S., Brace, M., Cantón, G., Cano, D., Leunda, M.R., Odeón, A.C., Odriozola, E. and Campero, C.M. (2009) Risk factors associated with Neospora caninum infections in cattle in Argentina. Vet. Parasitol., 161(1-2): 122-125.

31. Georgieva, D.A., Prelezov, P.N. and Koinarski, V.T.S. (2006) Neospora caninum and neosporosis in animals: A review. Bulg. J. Vet. Med., 9(1): 1-26.

32. Moore, D.P., Konrad, J.L., San Martino, S., Reichel, M.P., Cano, D.B., Méndez, S., Späth, E.J.L., Odeón, A.C., Crudeli, G. and Campero, C.M. (2014) Neospora caninum serostatus is affected by age and species variables in cohabiting water buffaloes and beef cattle. Vet. Parasitol., 203(3-4): 259-263. 